\title{
ANTICORROSION PROPERTIES OF ORGANIC COATINGS CONTAINING POLYPHENYLENEDIAMINE PHOSPHATE
}

\author{
Miroslav Kohl', Andréa Kalendová' \\ 1 Faculty of Chemical Technology, Institute of Chemistry and Technology of Macromolecular Materials, \\ University of Pardubice, Studentská 95, 53210 Pardubice, Czech Republic, e-mail: Miroslav.Kohl@seznam.cz; \\ Andrea.Kalendova@upce.cz
}

Received: 2015.10 .09

Accepted: 2015.11.14

Published: 2015.12.04

\begin{abstract}
The present work was aimed at the synthesis of polyphenylenediamine, its description and determination of parameters whose knowledge is required for the formulation of organic coatings pigmented with this compound. Polyphenylenediamine phosphate was prepared by oxidation polymerization in acidic environment. Phosphoric acid was used as the doping acid. Based on the results, pigmented organic coatings containing polyphenylenediamine at volume concentrations of $0 \%, 0.5 \%, 1 \%, 3 \% ; 5 \%$, and $10 \%$ were formed. The effect of the conductive polymer on the organic coatings ${ }^{6}$ corrosion properties was examined via accelerated corrosion tests. From the results of an accelerated corrosion test it follows that if added to an epoxy-ester coating, this pigment improves appreciably the coating's corrosion resistance, especially at low pigment volume concentrations.
\end{abstract}

Keywords: conductive polymers, polyphenylenediamine phosphate, organic coating, corrosion.

\section{INTRODUCTION}

Conductive polymers are attracting the interest in many branches of science and technology, including paint industry. Among important conductive polymers are polyphenylenediamine (Fig. 1), polyaniline and polypyrrole. Major advantages of such conductive polymers include easy preparation, high stability and non-toxicity, owing to which such substances can be used as ingredients in organic coatings. Polyaniline (PANI) has found application in many branches of science and technology. This conductive polymer is prepared by oxidative polymerization of aniline. A close relative is phenylenediamine (PPDA), which can also be oxidized to the oligomer or polymer [2, 3]. Three phenylenediamine isomers exist (Fig. 2), usable for oxidative polymerization as the base or in a form of salts (Fig. 3). The two species types are $\mathrm{pH}$-dependent and their oxidation patterns are different [4].
Phenylenediamine contains two primary amino groups, serving to interconnect the monomers during the oxidative polymerization process. Ammonium peroxodisulphate is used as the oxidative reagent. The two amino groups can be included in a phenazine-like ladder structure if the oxidative reagent is present in appreciable concentrations [5, 1] (Fig. 4.).

Polyphenylenediamine is considerably less conductive than polyaniline but many properties are similar owing to the similarity of the structures. Redox activity is one of such properties [4].

\section{EXPERIMENTAL PART}

Laboratory preparation of poly(p-phenylenediamine) phosphate PPDA- $\mathrm{H}_{3} \mathrm{PO}_{4}$

To prepare PPDA- $\mathrm{H}_{3} \mathrm{PO}_{4}$, phenylenediamine is oxidised by ammonium peroxodisulphate in an acidic medium. The reaction takes place in air at ambient temperature. 
<smiles>CNc1ccc(N=C2C=C(N)C(=[NH+]c3ccc(N(C)C)cc3)C(N)=C2)cc1</smiles>

Fig. 1. Chemical representation of poly-(para-phenylenediamine) [1]<smiles>Nc1ccccc1N</smiles><smiles>Nc1cccc(N)c1</smiles><smiles>Nc1ccc(N)cc1</smiles><smiles>Nc1ccc(N)cc1</smiles>

Fig. 2. Phenylenediamine bases: (a) ortho, (b) meta, and (c) para isomer [4]

Fig. 3. Phenylenediamine bases form salts with acids (HA) as illustratedon poly(p-phenylenediamine) [4]<smiles>CNc1cc2[nH]c3cc4[nH]c5cc6[nH]c7cc(NC)c(C)cc7[nH]c6cc5[nH]c4cc3[nH]c2cc1C</smiles>

Fig. 4. Idealized structure of poly(p-phenylenediamine) produced by the oxidation of both amine groups in pphenylenediamine [4]

$250 \mathrm{ml}$ of $0,2 \mathrm{M}$ phenylenediamine was dissolved in $0,2 \mathrm{M}$ phosphoric acid and $250 \mathrm{ml}$ of $0,25 \mathrm{M}$ potassium peroxodisulphate was dissolved in distilled water. The two solutions were mixed and the resulting liquid was stirred mechanically for 60 minutes. The reaction mixture was then left overnight. The resulting PPDA- $\mathrm{H}_{3} \mathrm{PO}_{4}$ precipitate was filtered off using a Buchner funnel, and the product was washed with dilute phosphoric acid $(0,2 \mathrm{M})$ and with acetone. The resulting PPDA$\mathrm{H}_{3} \mathrm{PO}_{4}$ powder was dried for 24 hours in air and subsequently in an oven at $60{ }^{\circ} \mathrm{C}$.

\section{Pigment specification}

$2 \%$ suspension of the pigment in redistilled water was then prepared and values of $\mathrm{pH}$ and conductivity were recorded for 28 days. The critical volume concentration of the pigments was calculated from the density determined using Autopycnometer Micromeritics 1320 and oil absorption was determined according to the Czech State Standard (CSN) 670531 using the "pestle - mortar" method. Determination of particle size and the distribution of pigment particle size were identified by means of Mastersizer 2000 (Malvern, Instruments Ltd., UK) that is able to measure the distribution of particles sized from 0.01 to $2000 \mu \mathrm{m}$.

\section{Formulation and preparation of organic coatings}

As a binder, the epoxy-ester resin was used. Organic coating materials with the PPDA- $\mathrm{H}_{3} \mathrm{PO}_{4}$ pigment were prepared at the pigment volume concentration (PVC) $0 \% ; 0,5 \% ; 1 \% ; 3 \% ; 5 \%$ and $10 \%$. Organic coatings were dispersed using a Disolver-type equipment at 4000 r.p.m. for 30 minutes. The description binder: W'Dur D 46, is a short oil epoxy ester based on conjugated drying fatty acids. It is used in air-drying and stoving finishes with outstanding adhesion, rapid drying and good chemical resistance.

\section{Corrosion test procedures}

Accelerated corrosion tests are based on the intensification of the effects of natural forces that have a decisive influence on the protective properties of the paints, their degradation, and primarily on the extent of corrosion under the paint film on a protected base.

The dry film thickness (DFT) was measured using a magnetic gauge in accordance with ISO 2808. To test the anticorrosive efficiency, a test cut (about $7 \mathrm{~cm}$ ) was made at the bottom of all paints. 
The degree of blistering on the surface of the coatings (ASTM D 714-78), the degree of corrosion at the test scribe (ASTM D 1654-92) and the degree of steel surface corrosion (ASTM D 610-85) were evaluated after the exposure in the corrosive environments.

\section{Accelerated cyclic corrosion test in an atmosphere of $\mathrm{NaCl}$ with water steam condensation (ISO 9227)}

The exposure of the samples in a testing chamber was performed in 12-h cycles divided into three parts: $6 \mathrm{~h}$ of exposure to a mist of $5 \%$-solution of $\mathrm{NaCl}$ at a temperature of $35{ }^{\circ} \mathrm{C}$; $2 \mathrm{~h}$ of exposure at a temperature of $23{ }^{\circ} \mathrm{C}$; and $4 \mathrm{~h}$ of humidity condensation at a temperature of $40{ }^{\circ} \mathrm{C}$. The samples were evaluated after $816 \mathrm{~h}$ of exposure.

\section{RESULTS}

\section{Pigment specification}

PPDA- $\mathrm{H}_{3} \mathrm{PO}_{4}$ pigment specification data and its microphotograph are presented in Table 1. PPDA- $\mathrm{H}_{3} \mathrm{PO}_{4}$ density is rather low, $1.69 \mathrm{~g} / \mathrm{cm}^{3}$, and so its sedimentation rate in organic coatings can be expected not to be very high. This assumption was verified by a test in which PPDA- $\mathrm{H}_{3} \mathrm{PO}_{4}$ storability and stability at room temperature was monitored during 120 days. No gel formation of viscosity change of the organic coatings was observed. The critical pigment volume concentration (CPVC), which depends on density and on the amount of oil spent, is a parameter whose knowledge is a prerequisite for a correct formulation of the pigmented organic coating. It reached $70 \%$ for $\mathrm{PPDA}-\mathrm{H}_{3} \mathrm{PO}_{4}$. It is well known that $\mathrm{pH}$ is a parameter that provides important information regarding the behaviour of pigments in the binder. The $\mathrm{pH}$ and specific conductivity of redistilled water from which the $2 \%$ pigment suspensions were prepared were $\mathrm{pH} 6.5 \pm 0.01$ and $1.5 \mu \mathrm{S} \cdot \mathrm{cm}^{-1}$, respectively. The acidity of the $2 \%$ suspensions was appreciably higher $(\mathrm{pH}$ as low as 2), and the conductivities were much higher as well, up to $3.1 \mathrm{mS} / \mathrm{cm}$. The mean particle size was $8.45 \mu \mathrm{m}$.

\section{Evaluation of accelerated corrosion tests}

The results regarding resistance of the organic coatings to a salt mist atmosphere are presented in Table 2. Exposure time was 1152 hours. The results demonstrate that the occurrence of blisters on the coating surface as well as in the cut is lower for organic coatings with PPDA- $\mathrm{H}_{3} \mathrm{PO}_{4}$ than for the non-pigmented organic coating. Organic coatings with PPDA$\mathrm{H}_{3} \mathrm{PO}_{4}$ at pigment volume concentrations (PVC) between $0.5 \%$ and $3 \%$, and in particular, between $0.5 \%$ and $1 \%$, deserve special attention because such coatings exhibited the highest corrosion resistance: corrosion in the cut was lower than $1 \mathrm{~mm}$ and corrosion on the panel surface was as low as $0.03 \%$, as opposed to the non-pigmented organic coating where corrosion in the cut reached $1.7 \mathrm{~mm}$ and corrosion on the panel surface attained $10 \%$.

Table 1. Characteristics of the $\mathrm{PPDA}-\mathrm{H}_{3} \mathrm{PO}_{4}$

\begin{tabular}{|c|c|c|c|c|c|c|}
\hline Sample & $\begin{array}{c}\text { Density } \\
{\left[\mathrm{g} / \mathrm{cm}^{3}\right]}\end{array}$ & $\begin{array}{c}\text { Oil absorption } \\
{[\mathrm{g} / 100 \mathrm{~g}]}\end{array}$ & $\begin{array}{c}\text { CPVC } \\
{[\%]}\end{array}$ & $\mathrm{pH}^{28}$ & $\begin{array}{c}\text { Conductivity } \\
{[\mathrm{mS} / \mathrm{cm}]}\end{array}$ & $\begin{array}{c}\text { Particle size } \mathrm{d}_{50} \\
{[\mu \mathrm{m}]}\end{array}$ \\
\hline PPDA- $_{3} \mathrm{PO}_{4}$ & $1.69 \pm 0.02$ & 23.7 & 70 & $2.00 \pm 0.01$ & $3.1 \pm 0.5 \%$ & $8.45 \pm 0.1$ \\
\hline
\end{tabular}

Table 2. Results of the corrosion tests performed in a salt mist chamber for coatings after $1152 \mathrm{~h}$ of exposure, $\mathrm{DFT}=70 \pm 10 \mathrm{~mm}$

\begin{tabular}{|c|c|c|c|c|c|}
\hline \multirow[b]{2}{*}{ Sample } & \multirow{2}{*}{$\frac{\text { PVC }}{[\%]}$} & \multicolumn{2}{|c|}{ Blistering } & \multicolumn{2}{|c|}{ Corrosion } \\
\hline & & Metal base $[\mathrm{dg}]$ & $\begin{array}{c}\text { In a cut } \\
\text { [dg] }\end{array}$ & $\begin{array}{c}\text { Metal base } \\
{[\%]}\end{array}$ & $\begin{array}{c}\text { In a cut } \\
{[\mathrm{mm}]}\end{array}$ \\
\hline \multirow{6}{*}{$\mathrm{PPDA}-\mathrm{H}_{3} \mathrm{PO}_{4}$} & 0 & $2 \mathrm{M}$ & $2 \mathrm{M}$ & 10 & 1.7 \\
\hline & 0.5 & $4 \mathrm{M}$ & $4 \mathrm{M}$ & 0.03 & 0.8 \\
\hline & 1 & $4 \mathrm{M}$ & $4 \mathrm{M}$ & 0.03 & 0.94 \\
\hline & 3 & $4 \mathrm{M}$ & $4 \mathrm{MD}$ & 3 & 1 \\
\hline & 5 & $4 \mathrm{MD}$ & $4 M D$ & 10 & 2.0 \\
\hline & 10 & $2 \mathrm{~F}$ & $4 \mathrm{M}$ & 10 & 1.4 \\
\hline
\end{tabular}




\section{CONCLUSIONS}

Polyphenylenediamine phosphate was synthesized and its parameters needed for the formulation of organic coatings containing this pigment were measured. From the results of an accelerated corrosion test it follows that if added to an epoxy-ester coating, this pigment improves appreciably the coating's corrosion resistance, especially at low pigment volume concentrations. Further investigations should be aimed at the identification of the mechanism of action of this pigment - polyphenylenediamine phosphate.

\section{REFERENCES}

1. do Nascimento G.M., Sestrem R.H., Temperini M.L.A. Structural characterization of poly-paraphenylenediamine montmorilloniteclay nanocomposites. Synthetic Metals, 160, 2010, 2397-2403.

2. Kang E.T., Neoh K.G., Tan K.L. Polyanilinu: polymer s mnoha zajímavými vnitřních redox stavů. Prog. Polym. Sci., 23, 1998, 277-324.

3. Li X.G., Huang M.R., Duan W. Nové multifunkční polymery z aromatických diaminy oxidační polymerace. Chem. Rev., 102, 2002, 2925-3030.

4. Stejskal J. Polymers of phenylenediamines. Progress in Polymer Science, 41, 2015, 1-31.

5. Mei-Rong Huang, Qian-Yun Peng, and Xin-Gui Li: Rapid and effective adsorption of lead ions on fine poly(phenylenediamine) microparticles. Chem. Eur. J. 12, 2006, 4341-4350. 